Canadian

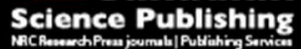

Canadian Journal of Forest Research Revue canadienne de recherche forestière

\title{
Effects of wind damage on the optimal management of boreal forests under current and changing climatic conditions
}

\begin{tabular}{|r|l|}
\hline Journal: & Canadian Journal of Forest Research \\
\hline Manuscript ID & cjfr-2016-0226.R2 \\
\hline Manuscript Type: & Article \\
\hline Date Submitted by the Author: & 18 -Oct-2016 \\
\hline Complete List of Authors: & $\begin{array}{l}\text { Zubizarreta-Gerendiain, Ane; University of Eastern Finland, School of } \\
\text { Forest Science; Basque Center for Climate Change, (BC3) } \\
\text { Pukkala, Timo; University of Eastern Finland, } \\
\text { Peltola, Heli; University of Eastern Finland, School of Forest Sciences }\end{array}$ \\
\hline Keyword: & $\begin{array}{l}\text { wind disturbance, risk management, carbon balance, spatial optimization, } \\
\text { forest landscape structure }\end{array}$ \\
\hline
\end{tabular}

\section{SCHOLARONE ${ }^{\text {'M }}$ \\ Manuscripts}


1 Effects of wind damage on the optimal management of boreal forests under current and

2 changing climatic conditions

3

4 Ane Zubizarreta-Gerendiain, ${ }^{1,2^{*}}$ Timo Pukkala, ${ }^{1}$ Heli Peltola ${ }^{1}$

5

6

$7{ }^{1}$ School of Forest Sciences, Faculty of Science and Forestry, University of Eastern Finland,

8 PO Box 111 FI-80101 Joensuu, Finland

$9{ }^{2}$ Basque Centre for Climate Change (BC3), 48008, Bilbao, Spain

10

11

$12 *$ Corresponding author

13 Ane Zubizarreta-Gerendiain

14 ane.zubizarreta@uef.fi

15 Phone number: +358 449667503; Fax: +358 294457316

16

17 Emails: Timo Pukkala, timo.pukkala@uef.fi

18

Heli Peltola, heli.peltola@uef.fi

19 


\section{Abstract}

21 This study presented a new method for considering the risk of wind damage in forest planning

22 and for predicting the amount of damage and its effects on timber production, economic

23 profitability and carbon balance of forestry. The effects of wind damage on the optimal

24 management of boreal forests under current and changing climatic conditions were analyzed

25 by comparing four forest management plans. A reference plan maximized net present value

26 (NPV) with even-flow harvesting constraints. The second plan minimized height differences

27 between adjacent stands and the third minimized height differences while simultaneously

28 maximizing NPV. The fourth plan maximized height differences between adjacent stands. To

29 obtain damage-adjusted results, schedules that belonged to the optimal management plans

30 were simulated with wind damage, taking into account the shelter provided by adjacent

31 stands. Maximizing NPV and simultaneously minimizing height differences resulted in the

32 highest damage-adjusted NPV. Increasing wind damage increased carbon balance of forest

33 soil, but decreased the total carbon balance of forestry as it decreased the carbon balances of

34 living forest biomass and wood-based products. Climate change slightly improved the total

35 carbon balance of forestry. If wind damage was ignored in calculations, NPV, total carbon

36 balance of forestry and timber production were overestimated.

37

38 Keywords: wind disturbance, risk management, carbon balance, spatial optimization, forest

39 landscape structure

40

41

42

43

44 
45

46

47

48

49

50

51

52

53 The susceptibility of tree stands to wind damage (uprooting or breakage of trees) is affected

54

55

56

57

\section{Introduction}

Storms and strong winds have caused large economic losses in forestry in central and northern Europe since the 1990s (e.g. Schelhaas et al. 2003). In Finland, strong winds have damaged in total about 24.1 million $\mathrm{m}^{3}$ of timber in different winter and summer storms between 2001 and 2014. The most timber was damaged in $2001\left(7.3\right.$ million $\left.\mathrm{m}^{3}\right)$ and 2010

(8.1 million $\mathrm{m}^{3}$ ) (Gregow 2013). Finland also experienced strong storms in 2002, 2011, 2012, 2013, and 2014, with the annual damage ranging from 0.3 to 4 million $\mathrm{m}^{3}$. by stand and site characteristics (Peltola et al. 1999a; Gardiner et al. 2008; Pukkala et al. 2016). Most wind damage occurs in mature stands adjacent to newly clear-cut areas or in recently heavily thinned mature stands, where trees have not acclimated to increasing wind loading (e.g. Laiho 1987; Zubizarreta-Gerendiain et al. 2012). Norway spruce (Picea abies Karst L.) with shallow rooting is more vulnerable to wind damage in Finnish conditions than Scots pine (Pinus sylvestris L.) and birch (Betula spp.) (Laiho 1987; Peltola et al. 1999b). The risk of wind damage may be decreased by avoiding new vulnerable edges, especially in mature stands, and by cutting first the most vulnerable older stands (Tarp and Helles 1997; Meilby et al. 2001; Zeng et al. 2007; Zubizarreta-Gerendiain et al. 2012). A smooth landscape structure with small height differences between adjacent stands has also been found to decrease the risk of wind damage (Zeng et al. 2007; Heinonen et al. 2009).

The risk of wind damage for a certain stand may be evaluated based on the characteristics of the stand itself and its immediate neighbor stands (e.g. Meilby et al. 2001; Zeng et al. 2007). Mechanistic wind damage risk models offer means to predict the threshold wind speeds needed to uproot or break trees in alternative management schedules, allowing calculation of 
70 the probability of wind damage based on local wind characteristics (Peltola et al. 1999b,

71 2010; Gardiner et al. 2000, 2008; Ancelin et al. 2004; Byrne and Mitchell 2013; Seidl et al.

72 2014; Dupont et al. 2015). Zeng et al. (2007) employed a forest ecosystem model and a

73 mechanistic risk model (HWIND) to calculate the risk of wind damage in an optimization

74 study. They showed that the total length of edges vulnerable to wind damage could be

75 decreased by aggregating clear-felling areas and by avoiding the creation of new clear-felling

76 areas at the edges of older and high stands.

77

78 Heinonen et al. $(2009,2011)$ developed simple regression models based on HWIND model

79 simulations (Peltola et al. 1999b) to predict the threshold wind speeds needed to uproot Scots

80 pine, Norway spruce, and birch. The critical wind speed was predicted from the

81 characteristics of the subject stand and the height of the adjacent upwind stand. Heinonen et

82 al. $(2009,2011)$ also showed that the risk of wind damage clearly affects the optimal cuttings

83 and the structure of forest landscapes. However, these previous studies did not actually

84 simulate wind damage or evaluate its effect on timber production and its profitability. Meilby

85 et al. (2001) were the firsts to analyze the influence of the risk of wind damage on the net

86 present value (NPV) and optimal rotation length of single stands considering the effect of

87 sheltering stands. In the presence of risk, the rotation length of unsheltered stands should be

88 shortened, whereas the rotation of stands providing wind shelter for other stands should be

89 lengthened (Meilby et al. 2001).

90

91 A warming climate may increase the risk of wind damage in Finland although the frequency

92 and severity of storms may not increase (Gregow et al. 2011). This is partly because the

93 frozen soil period, which currently improves tree anchorage from late autumn to early spring,

94 will become shorter (Blennow et al. 2010; Kellomäki et al. 2010; Gregow et al. 2011). 
95 Furthermore, forest growth and volume of growing stocks of Finnish forests are in general

96 expected to increase under the projected climate change (see e.g. Kellomäki et al. 2008).

97 Consequently, various abiotic and biotic risks to forests may increase, which should be taken

101

102

104

105

106

107

108

109

110

111

112

113

114

115

116

117

118

119

into account in forest management as they may greatly affect forest productivity, carbon

sequestration and stocks in forests (e.g. Lindner et al. 2010, 2014; Kolström et al. 2011; Seidl

et al. 2011; Subramanian et al. 2016; Thom and Seidl 2016).

In this work, the aim was to introduce a new method for considering the risk of wind damage in forest planning and demonstrate the effect on wind- risk-related management objectives on forest landscape structure. The amount of wind damage was predicted and the effect of damage on timber production, economic profitability and carbon balance of forestry was calculated. The carbon balance of forestry included changes in the carbon pools of living forest biomass, dead organic matter (soil), and wood products. The carbon balance of wood products also included carbon releases from harvesting, transport, and manufacturing, as well as the substitution effects arising from reduced carbon emissions from fossil fuels due to the use of construction wood and forest biomass-based fuels (see e.g. Zubizarreta Gerendiain et al. 2015). The effects of wind damage on the optimal management of the boreal forest landscape were demonstrated by comparing results for four alternative forest management plans under the current and gradually changing climate. It was assumed that under the gradually changing climate, the mean annual temperature will increase by $4{ }^{\circ} \mathrm{C}$, precipitation by $10 \%$, and atmospheric $\mathrm{CO}_{2}$ concentration by 272 ppm by $2070-2100$ compared to the current climate (period 1960-2000), following the SRES A1B scenario of the CMIP3 database (see IPCC 2013; Jylhä et al. 2009). A reference management plan maximized the economic profitability (NPV) with even-flow harvesting constraints. Other plans minimized height differences between adjacent stands as the only objective or aimed simultaneously at 
120 maximal NPV, or maximized height differences between adjacent stands to derive the extent

121 to which wind damage can be affected by forest management. Since the same treatment

122 schedules were simulated without and with wind damage, it was possible to calculate the

123 influence of wind damage on the timber production, NPV, and carbon balance of forestry. We

124 hypothesized that by ignoring wind damage in calculations, the NPV, total carbon balance of

125 forestry, and timber production are all overestimated.

126

\section{Materials and methods}

\section{Overview}

129 The analyzes of this study consisted of the following steps (Fig. 1):

130 1. Alternative treatments schedules were simulated for all stands of the study area without 131 predicting the amount of wind damage.

132 2. The optimal combination of simulated management schedules was derived by using 133 numerical optimization. Four alternative plans were compiled, referred to as the 134 MaxNPV, MinRisk, MaxRisk, and MaxNPV-MinRisk plans. The optimal solutions

135 together with the first-step simulations provided information about tree height 136 development in every stand of the landscape.

137 3. The optimal schedules selected for the stands in Step 2 were simulated again including 138 simulation of the wind damage at stand edges.

140 All steps were performed using the Monsu simulation-optimization system (Pukkala 2004).

141 All the models explained below were programmed in the Monsu software. The boreal forest

142 landscape used as a study area in this work represented the conditions of the southern part of 143 central Finland. It covered 360 ha, divided into 245 stands (Table 1). 
145 Figure 1, Table 1

146

147 Simulation of treatment schedules

148 The simulation tool Monsu was used to simulate alternative 30-year management schedules

149 for each stand. Based on a set of parameters (minimum basal area required for thinning

150 treatment and minimum mean tree diameter required for final felling) the tool automatically

151 simulated several treatment schedules for each stands and calculated the costs, removals,

152 incomes, NPV, carbon balance and growing stock development for each schedule. The

153 currently recommended site and species-specific thinning thresholds (stand basal area at

154 which thinning is recommended) and average diameter at breast height required for final

155 felling were applied (see Äijälä et al. 2014) to define the earliest possible time for thinning

156 and final felling. In the other schedules, the thinning treatments or the final felling were

157 postponed or were not done at all. Thinning from below was simulated so that half of the

158 harvested basal area was removed by using the same thinning intensity in all diameter classes.

159 Then, smallest diameter classes were removed until the post-thinning basal area reached the

160 recommended target value. After the final felling, artificial regeneration by planting or sowing

161 was used, except in Scots pine stands on sub-xeric and poorer sites where natural regeneration

162 was used. This is advised in Finnish forest management recommendations (see Äijälä et al.

163 2014). Stand development was simulated for three consecutive 10 -year periods. Thus, each

164 stand had several alternative treatments schedules for the coming 30 -year period.

165

166 The models of Pukkala et al. (2013) for diameter increment, tree survival and ingrowth were

167 used to simulate stand development. Stem taper models (Laasasenaho 1982) were used to

168 calculate assortment volumes of harvested trees (Table 2) and biomass models to calculate the

169 biomasses of branches, foliage, stumps, and coarse roots. When calculating incomes from 
170 timber sales, the assortment volumes of harvested trees were multiplied by the roadside prices

171 of different timber assortments (Table 2). Harvesting costs, calculated with the functions of

172 Rummukainen et al. (1995) were subtracted from the roadside value to obtain the net income

173 from cutting.

174

175 Table 2

176

177 To calculate the NPV of a treatment schedule, all costs and incomes of the simulated 30-year

178 period were discounted to the beginning of the period using a $6 \%$ discount rate. The NPV of

179 the growing stock at the end of the simulation period was predicted with an algorithm of

180 Pukkala $(2005,2015)$ and added to the NPV of the 30 -year simulation period.

181

182 The effects of climate change were simulated using the species- and site-specific growth trend

183 functions (multipliers of the diameter growth models) built by Pukkala and Kellomäki (2012)

184 for Norway spruce, Scots pine, and silver birch (Betula pendula) for their typical growing

185 conditions in central Finland $\left(62^{\circ} 40^{\prime} \mathrm{N}, 29^{\circ} 38^{\prime} \mathrm{E}, 94 \mathrm{~m}\right.$ a.s.1., 1050 d.d). Based on them, the

186 increase in tree diameter increment ranges from 0.27 to $0.52 \%$ per year for Norway spruce,

187 Scots pine, and silver birch, when the mean annual temperature increases by $4{ }^{\circ} \mathrm{C}$,

188 precipitation by $10 \%$, and atmospheric $\mathrm{CO}_{2}$ concentration by 272 ppm by $2070-2100$

189 compared to the current climate (period 1960-2000). As a comparison, based on the climate

190 data loaded from the latest CMIP5 database (IPCC 2013; van Vuuren et al. 2011) by the

191 Finnish Meteorological Institute, the mean annual temperature in Finland is expected to

192 increase by $3.3-5.5 \mathrm{C}^{\circ}$, precipitation by $11-18 \%$, and atmospheric $\mathrm{CO}_{2}$ concentration by $172-$

193447 ppm by 2070-2100 under greenhouse concentration pathways RCP4.5 and RCP8.5

194 (based on averages of 28 climate models). 


\section{Calculation of carbon balance}

197 Our calculations of the carbon balance of forestry considered changes in the carbon pools of

198 living forest biomass, dead organic matter (soil), and wood products (Fig. 2). The carbon

199 balance of living forest biomass depended on the net biomass growth of living trees,

200 regeneration, mortality and harvested amount of forest biomass. Inputs to the dead organic

201 matter pool consisted of dead trees, residues of harvested trees, and above- and below-ground

202 litter production of trees. Logging residues (tree tops and branches), stumps, and roots were

203 left in the forest and included in the soil carbon balance. Wind-thrown trees were not

204 harvested and were therefore added to the dead organic matter pool. Litter production was

205 calculated from the biomass of branches, foliage, coarse roots and fine roots using the same

206 species-specific turnover rates as in Pukkala (2014).

207

208 Figure 2

209

210 The soil and product carbon pools of each stand were initialized using the models of Pukkala

211 (2014). This was done because omitting the decomposition of initial pools would have

212 resulted in overestimated carbon balances. Inputs to the carbon pool of wood products

213 consisted of harvested wood during the calculation period, and output consisted of the

214 disposal of products based on defined product-specific lifetimes. The carbon balance of

215 products also included carbon releases from harvesting, transport, and manufacturing, as well

216 as the substitution effects arising from reduced carbon emissions from fossil fuels due to the

217 use of construction wood and forest biomass-based fuels (Pukkala 2014; Zubizarreta-

218 Gerendiain et al. 2016). Harvested stems were partitioned into saw log, pulpwood, and fuel

219 feedstock. Harvesting emissions (tonnes of carbon released per tonne of carbon contained in 
220 harvested biomass) decreased with increasing size (dbh) of harvested trees (see Pukkala

221 2011). Releases from transport were calculated from the fuel consumption of a truck for a

222 return trip of $150 \mathrm{~km}$ for round wood and $100 \mathrm{~km}$ for biofuel. Manufacturing releases for

223 production of sawn wood, chemical mass, mechanical mass and biofuel were adopted from

224 literature (Liski 2001; Pukkala 2014).

225

226 The simulation tool of the Monsu software uses the Yasso07 model (Liski et al. 2009; Tuomi

227 et al. 2011a,b) to simulate the decomposition of soil organic matter. In the Yasso 07 model,

228 the decomposition rate depends on the mean annual temperature, annual precipitation, and

229 temperature amplitude of the region (Liski et al. 2009; Tuomi et al. 2011a,b). All these

230 decomposition drivers were assumed to change according to the trend functions presented in

231 Zubizarreta-Gerendiain et al. (2016). These functions correspond to the SRES A1B climate

232 change scenario.

233

234 The disposal of the products was simulated by using a decay curve:

235

$236 Y_{t}=Y_{0} \mathrm{e}^{k t}$

237

238 where $Y_{0}$ is the initial mass, $Y_{t}$ is the remaining mass $t$ years later, and $k$ is the annual disposal

239 rate. The annual disposal rate was 0.02 (2\% per year) for sawn wood, plywood, and veneer,

2400.1 for paper products, and 0.3 for biofuel. A part of the sawn wood, plywood, veneer, and

241 paper products that was disposed of was assumed to be used as biofuel, having the same

242 substitution effect (0.8) as other biofuels (Pukkala 2014). The remaining part decomposed,

243 releasing $\mathrm{CO}_{2}$ to the atmosphere.

244 


\section{Optimizations}

246 Management was optimized by using the treatment schedules that were simulated without

247 wind damage. The following four optimization problems were solved (Table 3): 1)

248 maximizing NPV (MaxNPV); 2) minimizing the risk of wind damage (MinRisk) by

249 minimizing height differences between adjacent stands; 3) maximizing the risk of wind

250 damage (MaxRisk) by maximizing height differences between adjacent stands; and 4)

251 maximizing NPV and simultaneously minimizing the risk of wind damage (MaxNPV-

252 MinRisk). An even-flow cutting target of $25000 \mathrm{~m}^{3}$ was set for the three 10 -year periods. This

253 harvesting target is near the predicted 10-year volume increment of the forest.

255 Table 3

256

257 The optimization problems can be formulated as follows:

$258 \max$ or $\min z=Z(\mathbf{x})$

259 subject to

260

$q_{i}=Q_{i}(\mathbf{x})=25000, \quad i=1, \ldots, 3$

261

262 where $z$ is the objective function (NPV or mean height difference between adjacent stands, or

263 a combination of both), $Z$ is the procedure that calculates the value of the objective function

264 from the information of those treatment schedules that are included in the solution, $q_{i}$ is the

265 volume harvested during the 10-year period $i, Q_{i}$ is the procedure that calculates the harvested

266 volume of the solution, and $\mathbf{x}$ is a vector that indicates the ID numbers of those schedules that

267 are included in the solution. Since all problems except one were spatial, a heuristic method

268 (simulated annealing) was used to find the optimal combination of the simulated treatment

269 schedules (Lockwood and Moore 1992). 
Wind damage calculation

272 Optimization was used to find the optimal combination of the simulated treatment schedules.

273 Knowing the treatment schedule of every stand of the forest landscape provided information

274 on tree height development in the neighborhood of every stand. This information made it

275 possible to simulate wind damage.

276

277 The treatment schedules selected for the optimal plans were simulated again including

278 simulation of wind damage. The shelter provided by adjacent stands was taken into account in

279 the calculation of wind damage at a certain stand edge, based on mean height differences of

280 neighboring stands. The results from these repeated simulations were used to calculate wind-

281 damage-adjusted results for timber production, NPV, and the carbon balance of forestry.

283 To calculate the amount of wind damage, we first calculated the critical wind speeds (CWS)

284 needed to uproot trees at stand edges by employing the regression models of Heinonen et al.

285 (2009). These models use the characteristics of the subject stand (tree species, mean stand

286 height, and diameter/height ratio) and the adjacent (stand height and surface area) as

287 predictors for the CWS (for more details, see Heinonen et al. 2009). The gap diameter (mean

288 gap diameter for winds blowing from the adjacent stand) was assumed to be equal to the

289 diameter of a circle whose area is equal to the surface area of the stand.

291 Based on the predicted $C W S$ for each edge, the probability of the wind speed exceeding the 292 threshold speed for uprooting a tree at a stand edge was calculated. The model for the 293 probabilities of different maximum wind speeds was based on the daily maxima of 10-minute 294 average wind speeds measured at the Helsinki-Vantaa airport weather station (see more 
295 details in Peltola et al. 2010). These data were used to calculate the annual maxima, and from

296 long-term statistics it was possible to calculate probabilities for different maximum annual

297 wind speeds. The obtained empirical probabilities were used to fit the following logit model

298 for the probability of having wind speeds higher than $x \mathrm{~m} / \mathrm{s}$ at least once per year:

299

300

$y=21.79-1.058 x$

301

$\mathrm{P}[\max$ wind speed $\geq x]=\exp (y) /(1+\exp (y))$

302

303 where $y$ is the logit transformation of the observed probability of having wind speeds of at

304 least $x \mathrm{~m} / \mathrm{s}$. Since the time step of growth simulation was five years, the annual probability

305 obtained from Equation 5 was converted into a five-year probability as follows:

306

307

$\mathrm{P}[\max 5$-year wind speed $\geq x]=1-(1-\mathrm{P}[\max 1 \text {-year wind speed } \geq x])^{5}$

Damage was simulated on the basis of the $C W S$ calculated for a stand edge and the probability

310 of having such a wind speed during a five-year period. The directional distribution of strong

311 winds was not considered in this work to simplify the approach (see Heinonen et al. 2011). It

312 was assumed that wind throws occurred within an edge zone whose width was equal to the

313 mean tree height of the subject stand (Fig. 3). This was assumed because the predicted wind

314 speed for uprooting increases sharply within one to two tree heights from the edge, depending

315 on stand density (Peltola et al. 1999b). Most wind damage occurs in the immediate proximity

316 of the newly created stand edge (see Peltola et al. 1999b; Zubizarreta-Gerendiain et al. 2012).

317 The proportion of trees expected to be uprooted in a wind damage event was 0.03 (3\% of trees

318 uprooted or broken), calculated from the wind damage measurements done after the Pyry, 
319 Janika, and Mielikki storms (Zubizarreta-Gerendiain et al. 2012). As a result, the proportion

320 of trees damaged in an edge area was:

321

$322 \mathrm{P}[$ damaged within the edge zone $]=0.03 \times \mathrm{P}[\max 5$-year wind speed $>C W S]$

324 where $C W S$ is the critical wind speed calculated for the edge. The proportion of damaged

325 trees among all trees in the stand was equal to

326

$327 \mathrm{P}[$ damaged $]=\mathrm{P}[$ damaged within the edge zone $] \times$ Area of edge zone $/$ Area of stand

328

329 The proportion of trees that escaped damage at edge $i$ was

330

$331 s_{i}=1-\mathrm{P}[\text { damaged }]_{i}$

332

333 and the proportion of trees that escaped all damage occurring at any of the $n$ borders of the

334 stand was

335

$$
S=\prod_{i=1}^{n} s_{i}
$$

337 The survival probability of each tree of the stand, as predicted by the survival model of

338 Pukkala et al. (2013), was multiplied by $S$ to obtain the wind-risk-adjusted survival 339 probability.

340

341 Figure 3

342 
343 The strongest winds in Finland occur from late autumn to early spring (Peltola et al. 1999a).

344 Frozen soils provide a strong anchorage for trees against uprooting during the windiest season

345 of the year. It was assumed that climate change lengthens the period of non-frozen soil by

$346 \quad 0.17 \%$ per year (Kellomäki et al. 2010). Consequently, the amount of wind damage was

347 assumed to increase by $0.17 \%$ per year when climate change was assumed.

348

349 Results

$350 \quad$ Forest landscape structure

351 Consideration of the risk of wind damage had a strong influence on the forest landscape

352 structure (Fig. 4), regardless of the climatic conditions applied. When the risk of wind damage

353 was minimized by minimizing the height difference between adjacent stands (MinRisk), the

354 optimization resulted in a smooth forest landscape structure, whereas the MaxRisk plan

355 resulted in a rough one. At the beginning of the simulation period, the mean height difference

356 between adjacent stands was around $4 \mathrm{~m}$. At the end of the 30 -year period, it was around $5 \mathrm{~m}$

357 in the MinRisk and MaxNPV-MinRisk plans, $13 \mathrm{~m}$ in the MaxRisk plan, and $7 \mathrm{~m}$ in the

358 MaxNPV plan (Fig. 5).

359

360 Figures 4 and 5

361

362 When the risk of wind damage was minimized (MinRisk), the thinned area was larger than the 363 clear-felled area (Fig. 6). The opposite was true for the MaxRisk plan. Climate change did not 364 substantially affect the thinned and clear cut areas, since the periodical cutting target was 365 equal in all optimizations.

366

367 Figure 6 
Net present value, timber production, and carbon balance of forestry

370 Wind damage affected the NPV and 30-year carbon balance of forestry. Under the current

371 climate, the MaxNPV and MaxNPV-MinRisk plans had the highest damage-adjusted NPV.

372 They also resulted in the highest timber production. The MinRisk and MaxRisk plans had 7 to

$37313 \%$ lower NPV and 4 to 19\% lower timber production (Table 4). Climate change increased

374 NPV by $1-2 \%$ and timber production by $4-10 \%$ compared to the corresponding plan under

375 the current climate.

376

377 Table 4

378

379 Under the current climate, the MaxNPV and MaxNPV-MinRisk plans had the highest total 380 carbon balance of forestry during the 30-year calculation period (Fig. 7). The MinRisk and

381 MaxRisk plans had 18 and 44\% lower carbon balances, respectively, compared to the

382 MaxNPV plan (Table 4). The carbon balance of living forest biomass was negative in all 383 optimization problems (ranging from -0.71 to -1.07 tonnes $\mathrm{ha}^{-1} \mathrm{y}^{-1}$ ) because of wind damage 384 and the fact that the harvesting target was slightly higher than the damage-adjusted volume 385 increment of the forest. The MaxRisk plan had up to 50\% lower carbon balance of living 386 forest biomass than the MaxNPV and MaxNPV-MinRisk plans, mainly due to the high 387 amount of wind damage in the MaxRisk plan. The carbon balances of forest soil and wood 388 products were positive (Fig. 7). The carbon balance of wood products was almost equal in all 389 plans because the target for the harvested volume was constant. Climate change improved the 390 total carbon balance slightly.

$392 \quad$ Figure 7 
394 Bias caused by omitting wind damage in calculations

395 Simulation of the optimal management both with and without wind damage made it possible

396 to calculate the bias caused by omitting wind damage in the calculations (Fig. 8). In this

397 study, positive bias means that omitting wind damage leads to an overestimated value of the 398 variable in question.

$400 \quad$ Figure 8

401

402 Figure 8 shows that the NPV, timber production, and carbon balance of forestry were all 403 overestimated, regardless of the plan and climatic conditions, when wind damage was not 404 taken into account. The MaxRisk plan resulted in the largest overestimation because it had 405 more simulated wind damage than the other plans. Under both climatic conditions, timber 406 production and the carbon balance of forestry were overestimated by $10-12 \%$ and the NPV by 407 around 3\%. The bias was smallest in plans that minimized the risk of wind damage.

409 When the bias in carbon balance was calculated separately for the three carbon pools, it 410 turned out that the carbon balance of forest soil was underestimated if wind damage was not 411 simulated (Fig. 8). This was because wind-thrown trees were treated as coarse woody debris, 412 which was treated as input to the soil carbon pool. Ignoring wind damage led to overestimated 413 carbon balances of living biomass and wood products since wind damage decreased the 414 carbon inputs to these two pools (Fig. 9).

415

416 Figure 9 


\section{Discussion and conclusions}

419 This study introduced and demonstrated the use of a new method of considering the risk of

420 wind damage in forest planning and predicting the amount of damage and their effects on

421 timber production, economic profitability and carbon balance of forestry. This methodology

422 could be easily applied to other forest regions where sufficient input data are available. The

423 method used for simulating wind damage could also be used to further analyze the effect of

424 wind damage on the amount and type of deadwood in the forests. This would provide

425 valuable information on the forest as habitat for many endangered species that depend on

426 deadwood (see, e.g., Tikkanen at al. 2007).

427

428 In our case study forest, wind damage decreased timber production in all management plans

429 regardless of climatic conditions, since it reduced both growth and harvested amount of

430 timber when damaged trees were left in the forest. The MaxNPV and MaxNPV-MinRisk

431 plans had the highest damage-adjusted timber production and MinRisk and MaxRisk plans

432 had the lowest. Consideration of the risk of wind damage in management planning did not

433 decrease the economic profitability of forestry when the NPV was maximized simultaneously

434 with the minimization of vulnerable stand edges (MaxNPV-MinRisk plan).

435

436 Our results also showed that if the risk of wind damage is minimized in the management

437 planning of even-aged forestry, the forest landscape structure becomes smoother than without

438 wind risk minimization. This was found also by Heinonen et al. (2009). Most probably the

439 effect would be much smaller in continuous cover forestry because it does not use clear-

440 fellings, which are the cause of vulnerable new stand edges (Pukkala et al. 2016). We also

441 demonstrated that without considering wind damage in calculations, the predicted NPV,

442 timber production, and total carbon balance of forestry are all overestimated. However, the 
443 soil carbon balance is underestimated if wind damage is ignored in calculations, because

444 damaged trees will increase the soil carbon balance if not harvested.

445

446 The MaxNPV and MaxNPV-MinRisk plans had the highest NPV and carbon balance of

447 forestry, regardless of the climatic conditions. When wind damage was not simulated, the

448 MaxNPV plan had a higher NPV than the MaxNPV-MinRisk plan. However, the MaxNPV

449 plan had more wind damage, which decreased its damage-adjusted NPV. As a result, when

450 wind damage was taken into account, the plan in which NPV was maximized and the risk of

451 wind damage simultaneously minimized eventually gave a slightly higher NPV than was

452 obtained under the MaxNPV plan. A similar conclusion was drawn earlier by Forsell et al.

453 (2011).

454

455 For all planning problems and climatic conditions, the harvested timber volume was set to

$45625000 \mathrm{~m}^{3}$ per 10-year period. However, the management actions needed to obtain the same

457 volume varied depending on the planning problem. Minimization of the risk of wind damage

458 increased the thinned area and decreased the clear-felled area when the same total timber

459 harvest target was applied since, opposite to clear-felling, thinning treatments did not increase

460 the length of vulnerable stand edges. Minimization of the risk of wind damage resulted in a

461 smoother landscape due to the decreased height differences between adjacent stands.

462

463 Similar to our study, Zeng et al. (2007) showed that the risk of wind damage could be

464 decreased by aggregating clear-felled areas due to the decrease in the length of vulnerable

465 edges. Heinonen et al. $(2009,2011)$ also demonstrated that the risk of wind damage could be

466 decreased significantly by minimizing the height differences between adjacent stands. Other

467 authors have also suggested that the shelter provided by a neighboring stand reduces the 
468 vulnerability to wind damage (Meilby et al. 2001; Schelhaas et al. 2007; Seidl et al. 2014;

469 Pukkala et al. 2016). Meilby et al. (2001) also suggested that increased rotation lengths should 470 be used for those stands that provide shelter to other stands.

471

472 Climate change is expected to increase forest growth, growing stock volume and timber 473 production potential in Finnish forests, although the growth of Norway spruce with shallow

474 rooting is expected to suffer drought on soils with low water holding capacity in the southern 475 part of the country (Kellomäki et al. 2008). The increasing growing stock volume may 476 increase the risks of various abiotic and biotic damages, which may change the carbon stocks 477 of forests (Schelhaas et al. 2003; Thom and Seidl 2016). Similarly, climate change is expected 478 to intensify natural disturbance regimes in forests (e.g. by wind storms, forest fires, bark 479 beetle and root rot damages), of which biodiversity will generally benefit while a sustainable 480 provisioning of other ecosystem services like timber might suffer (Jönsson et al. 2009;

481 Subramanian et al. 2016; Thom and Seidl 2016). In this study, we did not consider these 482 issues, but they should be taken into account in future studies.

483 Consideration of various risks to forests is becoming increasingly important under the 484 changing climate due to the increase of associated risks to forests. However, risk management 485 may be challenging if the forest holdings are very small like currently in Finland (20-30 ha 486 on average). Co-operation between neighboring forest holdings is needed when planning 487 forest management actions because the risk of wind damage within a single forest holding 488 depends on the management of adjacent holdings.

490 To conclude, our work demonstrated well that by using a simple approach, namely 491 minimizing height differences between adjacent stands, it is possible to decrease wind 
492 damage without reducing the economic profitability of forestry. It also showed that

493 consideration of wind damage in forest management planning clearly affects the development

494 of the forest landscape structure due to the effects of risk management objectives on the type,

495 location, and timing of cuttings. Minimization of the risk of wind damage increases the

496 thinned area, whereas it decreases the clear-felled area. But results may vary depending on the

497 initial forest structure and wind climate of the region (i.e. directional distribution of strong

498 winds and their probability).

499

500 Acknowledgments

501 This work was partly funded by the UEF foundation (project 930341 at the University of

502 Eastern Finland). It was also supported by the ADAPT project (no. 14907, 2012-2016) and

503 the Strategic Research Project FORBIO (no. 14970, 2015-2017), which are funded by the

504 Academy of Finland and led by Prof. Heli Peltola at UEF.

505

506

507

508 Äijälä, O., Koistinen, A., Sved, J., Vanhatalo, K., and Väisänen, P. (eds). 2014. Hyvän

510

511

\section{References} metsänhoidon suositukset - Metsänhoito (Recommendations for good forest management - forest management), Forestry Development Centre Tapio. 264 p. (In Finnish).

Ancelin, P., Courbaud, B., and Fourcaud, T. 2004. Development of an individual tree-based mechanical model to predict wind damage within forest stands. For. Ecol. Manag. 203: 101-121. doi:10.1016/j.foreco.2004.07.067.

515 Blennow, K., Andersson, M., Sallnäs, O., and Olofsson, E. 2010. Climate change and the 516 probability of wind damage in two Swedish forests. For. Ecol. Manag. 259: 818-830. 517 doi:10.1016/j.foreco.2009.07.004. 
518 Byrne, K., and Mitchell, S. 2013. Testing of WindFIRM/ForestGALES-BC: a hybrid-

519 mechanistic model for predicting windthrow in partially harvested stands. Forestry $\mathbf{8 6}$ :

520 185-199. doi:10.1093/forestry/cps077.

521 Dupont, S., Ikonen, V-P., Väisänen, H., and Peltola, H. 2015. Predicting tree damage in

522 fragmented landscapes using a wind risk model coupled with an airflow model. Can. J.

523 For. Res. 5: 1065-1076. dx.doi.org/10.1139/cjfr-2015-0066.

524 Forsell, N., Wikström, P., García, F., Sabbadin, R., Blennow, K., and Eriksson, L.O. 2011.

525 Management of the risk of wind damage in forestry: a graph-based Markov decision

526 process approach. Ann. Oper. Res. 190: 57-74. doi:10.1007/s10479-009-0522-7.

527 Gardiner, B.A., Peltola, H., and Kellomäki, S. 2000. Comparison of two models for predicting

528 the critical wind speeds required to damage coniferous trees. Ecol. Model. 129: 1-23.

529 doi:10.1016/S0304-3800(00)00220-9.

530 Gardiner, B.A., Byrne, K., Hale, S., Kamimura, K., Mitchell, S.J., Peltola, H., and Ruel, J.C.

531 2008. A review of mechanistic modelling of wind damage risk to forests. Forestry 81(3):

532 447-463. doi:10.1093/forestry/cpn022.

533 Gregow, H., Peltola, H., Laapas, M., Saku, S., and Venäläinen, A. 2011. Combined

534 occurrence of wind, snow loading and soil frost with implications for risks to forestry in

535 Finland under the current and changing climatic conditions. Silv. Fenn. 45(1): 35-54.

536 doi:10.14214/sf.30.

537 Gregow, H. 2013. Impacts of strong winds, heavy snow loads and soil frost conditions on the 538 risks to forests in Northern Europe. Finn. Meteorol. Inst. Contrib. 94: 1-178.

539 Heinonen, T., Pukkala, T., Ikonen, V.-P., Peltola, H., Venäläinen, A., and Dupont, S. 2009.

$540 \quad$ Integrating the risk of wind damage into forest planning. For. Ecol. Manag. 258: 1567-

541 1577. doi:10.1016/j.foreco.2009.07.006. 
542 Heinonen, T., Pukkala, T., Ikonen, V.-P., Peltola, H., Gregow, H., and Venäläinen A. 2011. 543 Consideration of strong winds, their directional distribution and snow loading in wind risk 544 assessment related to landscape level forest planning. For. Ecol. Manag. 261: 710-719. 545 doi:10.1016/j.foreco.2010.11.030.

IPCC, 2013. Summary for Policymakers. In Climate Change 2013: The Physical Science Basis. Contribution of Working Group I to the Fifth Assessment Report of the Intergovernmental Panel on Climate Change. Edited by T.F. Stocker, D. Qin, G.-K. Plattner, M. Tignor, S.K. Allen, J. Boschung, A. Nauels, Y. Xia, V. Bex, and P.M. Midgley. Cambridge University Press, Cambridge, United Kingdom and New York, NY, USA. Jönsson, A.M., Appelberg, G., Harding, S., Bärring, L., 2009. Spatio-temporal impact of climate change on the activity and voltinism of the spruce bark beetle, Ips typographus. Global Change Biology 15: 486-499.

546 Jylhä, K., Ruosteenoja, K., Räisänen, J., Venäläinen, A., Tuomenvirta, H., Ruokolainen, L.,

547 Saku, S., and Seitola, S. 2009. Arvioita Suomen muuttuvasta ilmastosta

548 sopeutumistutkimuksia varten. ACCLIM-hankkeen raportti 2009 [The changing climate in

549 Finland: estimates for adaptation studies. ACCLIM project report 2009]. Ilmatieteen laitos,

550 Raportteja 2009, p. 102. (In Finnish; abstract, extended abstract, and captions for figures

551 and tables also in English).

552 Kellomäki, S., Peltola, H., Nuutinen, T., Korhonen, K. T., and Strandman, H. 2008.

553 Sensitivity of managed boreal forests in Finland to climate change, with implications for 554 adaptive management. Philos. Trans. R. Soc. B: Biol. Sci. 363(1501): 2341-2351.

555 Kellomäki, S., Maajärvi, M., Strandman, H., Kilpeläinen, A., and Peltola, H. 2010. Model

556 computations on the climate change effects on snow cover, soil moisture and soil frost in 557 the boreal conditions over Finland. Silv. Fenn. 44(2): 213-233. Available from 558 http://www.metla.fi/silvafennica/full/sf44/sf442213.pdf [accessed 3 May 2016]. 
559 Kolström, M., Lindner, M., Vilén, T., Maroschek, M., Seidl, R., Lexer, M.J., Netherer, S.,

560 Kremer, A., Delzon, S., Barbati, A., Marchetti, M., and Corona, P. 2011. Reviewing the

561 science and implementation of climate change adaptation measures in European forestry.

$562 \quad$ Forests 2: 961-982. doi:10.3390/f2040961.

563 Laasasenaho, J. 1982. Taper curve and volume equations for pine spruce and birch. Commun.

564 Inst. For. Fenn. 108:1-74.

565 Laiho, O. 1987. Metsiköiden alttius tuulituhoille Etelä-Suomessa [Susceptibility of forest

566 stands to wind throw in Southern Finland]. Folia For. 706: 1-24. (In Finnish with English

567 summary).

568 Lindner, M., Fitzgerald, J.B., Zimmermann, N.E., Reyer, C., Delzon, S., van der Maaten, E.,

569 Schelhaas, M.J., Lasch, P., Eggers, J., van der Maaten-Theunissen, M., Suckow, F., Psomas,

570 A., Poulter, B., and Hanewinkel, M. 2014. Climate change and European forests: What do

571 we know, what are the uncertainties, and what are the implications for forest management?

572 J. Environ. Manag. 146: 69-83. doi:10.1016/j.jenvman.2014.07.030.

573 Lindner, M., Maroschek, M., Netherer, S., Kremer, A., Barbati, A., Garcia-Gonzalo, J., Seidl,

574 R., Delzon, S., Corona, P., Kolström, M., Lexer, M.J., and Marchetti, M. 2010. Climate

575 change impacts, adaptive capacity, and vulnerability of European forest ecosystems. For.

576 Ecol. Manag. 259: 698-709. doi:10.1016/j.foreco.2009.09.023.

577 Liski J, Pussinen A, Pingoud K, Mäkipää R, and Karjalainen T. 2001.Which rotation length is

578 favourable to carbon sequestration? Can. J. For. Res. 31, 2004-2013

579 Liski, J., Tuomi, M., and Rasinmäki, J. 2009. Yasso07 User-Interface Manual. Finnish

580 Environment Institute (www.environment.fi/syke/yasso). 12 pp. + Appendix.

581 Lockwood, C., and Moore, T. 1992. Harvest scheduling with spatial constraints: A simulated

582 annealing approach. Can. J. For. Res. 23: 468-478. doi:10.1139/x93-065. 
583 Meilby, H., Niels Strange, N., and Thorsen, B.J. 2001. Optimal spatial harvest planning under 584 risk of windthrow. For. Ecol. Manag. 149(1-3): 15-31. doi:10.1016/S0378-

$585 \quad 1127(00) 00542-9$.

586 Peltola, H., Kellomäki, S., and Väisänen, H. 1999a. Model computations on the impact of

587 climatic change on the windthrow risk of trees. Clim. Change 41: 17-36.

588 Peltola, H., Kellomäki, S., Väisänen, H., and Ikonen, V-P. 1999b. A mechanistic model for 589 assessing the risk of wind and snow damage to single trees and stands of Scots pine, 590 Norway spruce and birch. Can. J. For. Res. 29: 647-661. doi:10.1139/x99-029.

591 Peltola, H., Ikonen, V-P., Gregow, H., Strandman, H., Kilpeläinen, A., Venäläinen, A., and 592 Kellomäki, S. 2010. Impacts of climate change on timber production and regional risks of 593 wind-induced damage to forests in Finland. For. Ecol. Manag. 260(5): 833-845.

594 doi:10.1016/j.foreco.2010.06.001.

595 Pukkala, T. 2004. Dealing with ecological objectives in the Monsu planning system. Silva $596 \quad$ Lusit. (Special issue) 1-15.

597 Pukkala, T. 2005. Metsikön tuottoarvon ennustemallit kivennäismaan männiköille, 598 kuusikoille ja rauduskoivikoille. Metsätieteen aikakauskirja 3: 311-322. (In Finnish). 599 Pukkala, T. 2011. Optimising forest management in Finland with carbon subsidies and taxes. $600 \quad$ For. Policy Econ. 13: 425-434. doi:10.1016/j.forpol.2011.06.004.

601 Pukkala, T. 2014. Does biofuel harvesting and continuous cover management increase carbon 602 sequestration? For. Policy Econ. 43: 41-50.doi:10.1016/j.forpol.2014.03.004.

603 Pukkala, T. 2015. Plenterwald, Dauerwald, or clearcut? For. Policy Econ. 62: 125-134.

604 Pukkala, T., and Kellomäki, S. 2012. Anticipatory vs. adaptive optimisation of stand 605 management when tree growth and timber prices are stochastic. Forestry 85(4): 463-472.

606 doi: 10.1093/forestry/cps043.

607 Pukkala, T., Lähde, E., and Laiho, O. 2013. Species interactions in the dynamics of even- and 
608

609

610

611

612

613

614

615

616

617

618

619

620

621

622

623

624

625

626

627

628

629

630

631

632

uneven-aged boreal forests. J. Sustain. For. 32: 1-33. doi: $10.1080 / 10549811.2013 .770766$.

Pukkala, T., Laiho, O., and Lähde, E. 2016. Continuous cover management reduces wind damage. For. Ecol. Manag. 372: 120-127. doi: 10.1016/j.foreco.2016.04.014.

Rummukainen, A., Alanne, H., and Mikkonen, E. 1995. Wood procurement in the pressure of change - resource evaluation model till year 2010. Acta For. Fenn. 248: 1-98.Schelhaas, M.J., Nabuurs, G.J., and Schuck, A. 2003. Natural disturbances in the European forests in the 19th and 20th centuries. Glob. Change Biol. 9: 1620-1633. doi:10.1046/j.15298817.2003.00684.x.

Schelhaas, M.J., Nabuurs, G.J., Schuck, A., 2003. Natural disturbances in the European forests in the $19^{\text {th }}$ and $20^{\text {th }}$ centuries. Global Change Biology 9: 1620-1633.

Schelhaas, M.J., Kramer, K, Peltola, H., van der Werf, D.C., and Wijdevena S.M.J. 2007. Introducing tree interactions in wind damage simulation. Ecol. Model. 207: 197-209. doi:10.1016/j.ecolmodel.2007.04.025.

Seidl, R. Schelhaas, M.-J., and Lexer M.J. 2011. Unraveling the drivers of intensifying forest disturbance regimes in Europe. Glob. Change Biol. 17: 2842-2852.

Seidl, R. Rammer, W., and Blennow K. 2014. Simulating wind disturbance impacts on forest landscapes: tree-level heterogeneity matters. Environ. Model. Softw. 51: 1-11. doi:10.1016/j.envsoft.2013.09.018.

Subramanian, N., Bergh, J., Johansson, U., Nilsson, U., and Sallnäs, O. 2016. Adaptation of forest management regimes in southern Sweden to increased risks associated with climate change. Forests 7(1), doi:10.3390/f7010008.

Tarp, P., and Helles, F. 1997. Spatial optimisation by simulated annealing and linear programming. Scand. J. For. Res. 12: 390-402. doi:10.1080/02827589709355428.

Thom, D., and Seidl R. 2016. Natural disturbance impacts on ecosystem services and 
633 biodiversity in temperate and boreal forests. Biol. Rev. 91: 760-781. doi:

$634 \quad 10.1111 /$ brv. 12193.

635 Tikkanen, O.-P., Heinonen, T., Kouki, J., and Matero, J. 2007. Habitat suitability models of 636 saproxylic red-listed boreal forest species in long-term matrix management: Cost-effective 637 measures for multi-species conservation. Biol. Conserv. 140: 359-372. 638 doi:10.1016/j.biocon.2007.08.020.

639 Tuomi, M., Rasinmäki, J., Repo, A., Vanhala, P., and Liski, J. 2011a. Soil carbon model 640 Yasso07 graphical user interface. Environ. Model. Softw. 26(11): 1358-1362. 641 doi:10.1016/j.envsoft.2011.05.009.

642 Tuomi, M., Laiho, R., Repo, A., and Liski, J. 2011b. Wood decomposition model for boreal 643 forests. Ecol. Model. 222(3): 709-718. doi:10.1016/j.ecolmodel.2010.10.025.

Van Vuuren, D.P., Edmonds, J.A., Kainuma, M., Riahi, K., Thomson, A.M., Hibbard, K., Hurtt, G.C., Kram, T., Krey, V., Lamarque, J.-F., Masui, T., Meinshausen, M., Nakicenovic, N., Smith, S.J., and Rose, S. 2011. The representative concentration pathways: an overview. Clim. Change 109: 5-31. doi:10.1007/s10584-011-0148-z.

644 Zeng, H., Pukkala, T., and Peltola, H. 2007. The use of heuristic optimisation in risk 645 management of wind damage in forest planning. For. Ecol. Manag. 241: 189-199. 646 doi:10.1016/j.foreco.2007.01.016.

647 Zubizarreta-Gerendiain, A., Pellikka, P., Garcia-Gonzalo, J., Ikonen, V-P., and Peltola, H. 648 2012. Factors affecting wind and snow damage of individual trees in a small management 649 unit in Finland: Assessment based on inventoried damage and mechanistic modelling. Silv. 650 Fenn. 46(2): 181-196. doi:10.14214/sf.441.

651 Zubizarreta-Gerendiain, A., Pukkala, T., and Peltola, H. 2016. Effects of wood harvesting and 652 utilisation policies on the carbon balance of forestry under changing climate: A Finnish 653 case study. For. Pol. Econ. 62: 168-176. doi:10.1016/j.forpol.2015.08.007. 
654 
Table 1. Characteristics of the study area.

\begin{tabular}{|c|c|}
\hline Total forest area, ha & 360 \\
\hline Forest biomass, (above and below ground), tonnes ha ${ }^{-1}$ & 165 \\
\hline - Scots pine (Pinus sylvestris) $(\%)$ & 10.4 \\
\hline - $\quad$ Norway spruce (Picea abies) $(\%)$ & 46.1 \\
\hline - Betula spp. & 43.4 \\
\hline Total carbon stock, tonnes ha ${ }^{-1}$ & 256 \\
\hline - Trees & 72 \\
\hline - Mineral soils & 184 \\
\hline
\end{tabular}


655 Table 2. Minimum top diameters and roadside prices of different timber assortments of the 656 main species.

Scots pine $\quad$ Norway spruce Birch

Minimum top diameter, $\mathrm{cm}$

- Saw $\log$

15

16

18

- Pulpwood

7

8

7

Minimum piece length, $\mathrm{m}$

- Saw log

4.3

4.3

3.4

- Pulpwood

3

3

3

Roadside price, $€ \mathrm{~m}^{-3}$

- Saw $\log$

- Pulpwood 
658 Table 3. Optimization problems.

Short name Description

MaxNPV NPV was maximized. Wind risk management was not an objective.

Risk of wind damage was minimized by minimizing height differences

MinRisk between adjacent stands. NPV was not an objective.

Risk of wind damage was maximized by maximizing height differences

MaxRisk between adjacent stands. The purpose was to calculate the maximum possible wind damage. NPV was not an objective.

MaxNPV-

NPV was maximized and height differences between adjacent stands were

MinRisk minimized to find equilibrium between the economic profit and the losses due to wind damage. 
660 Table 4. Damage-adjusted net present value (NPV, 6\%), 30-year timber production and 30-

661 year carbon balance of forestry under the current climate (CU) and gradually changing

662 climate (CC) in four management plans (see Table 3 for more detailed explanations of the

663 management plans).

\begin{tabular}{|c|c|c|c|c|c|c|}
\hline \multirow[t]{2}{*}{ Management plan } & \multicolumn{2}{|c|}{$\begin{array}{l}\text { NPV } \\
\left(€ \mathrm{ha}^{-1}\right)\end{array}$} & \multicolumn{2}{|c|}{$\begin{array}{l}\text { Timber production } \\
\left(\mathrm{m}^{3} \mathrm{ha}^{-1} \mathrm{y}^{-1}\right)\end{array}$} & \multicolumn{2}{|c|}{$\begin{array}{l}\text { Carbon balance of forestry } \\
\text { (tonnes } \mathrm{ha}^{-1} \mathrm{y}^{-1} \text { ) }\end{array}$} \\
\hline & $\mathrm{CU}$ & $\mathrm{CC}$ & $\mathrm{CU}$ & $\mathrm{CC}$ & $\mathrm{CU}$ & $\mathrm{CC}$ \\
\hline MaxNPV & 4647 & 4721 & 4.25 & 4.72 & 0.88 & 0.98 \\
\hline MinRisk & 4331 & 4392 & 4.09 & 4.46 & 0.72 & 0.82 \\
\hline MaxRisk & 4042 & 4077 & 3.43 & 4.17 & 0.50 & 0.58 \\
\hline MaxNPV-MinRisk & 4649 & 4724 & 4.19 & 4.83 & 0.87 & 1.01 \\
\hline
\end{tabular}

664

665 


\section{FIGURES}

667

668

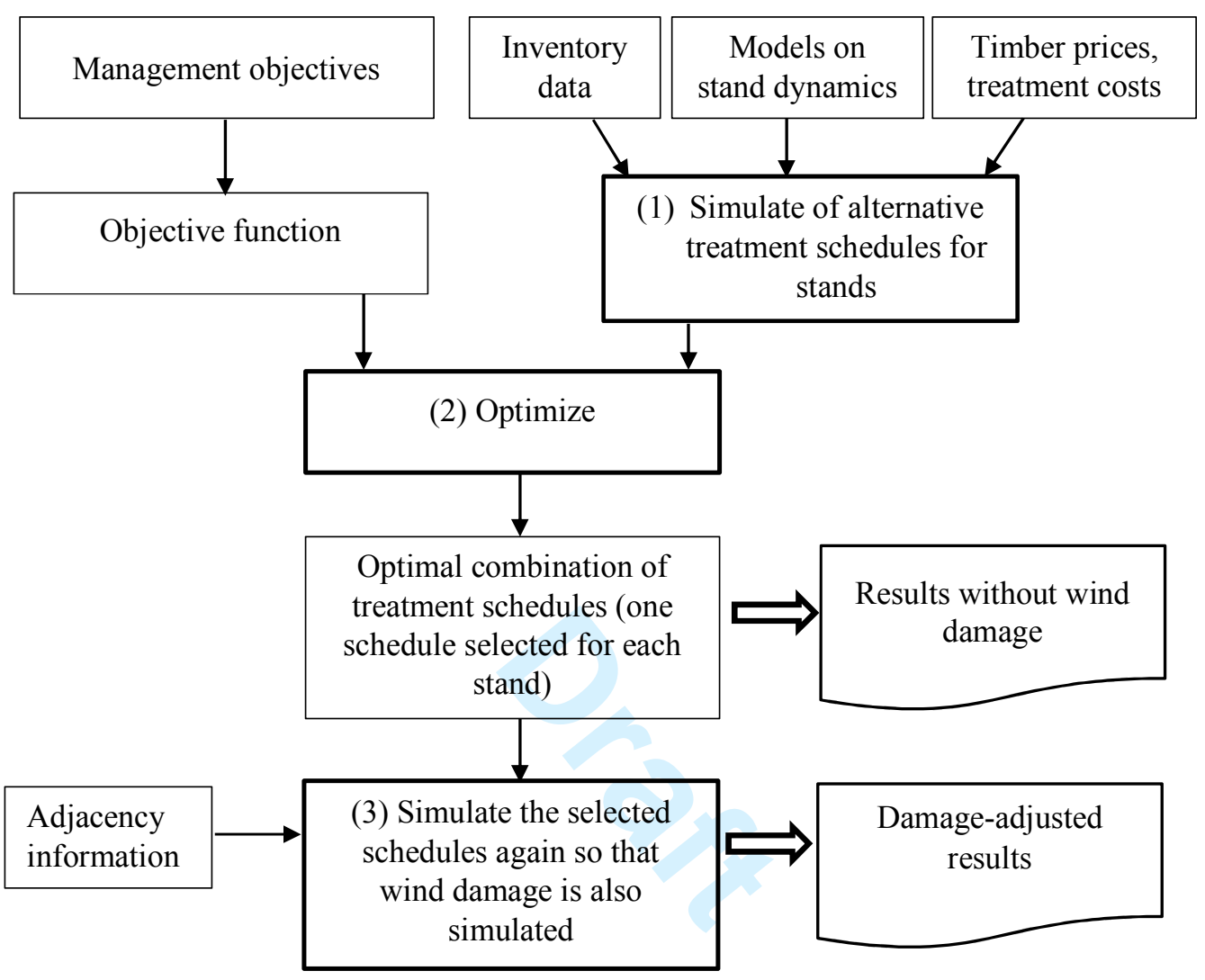

671 Figure 1. Flow chart of the method developed for analyzing the effects of wind damage.

672 Numbers correspond to the numbering of the main steps explained in the text

673 


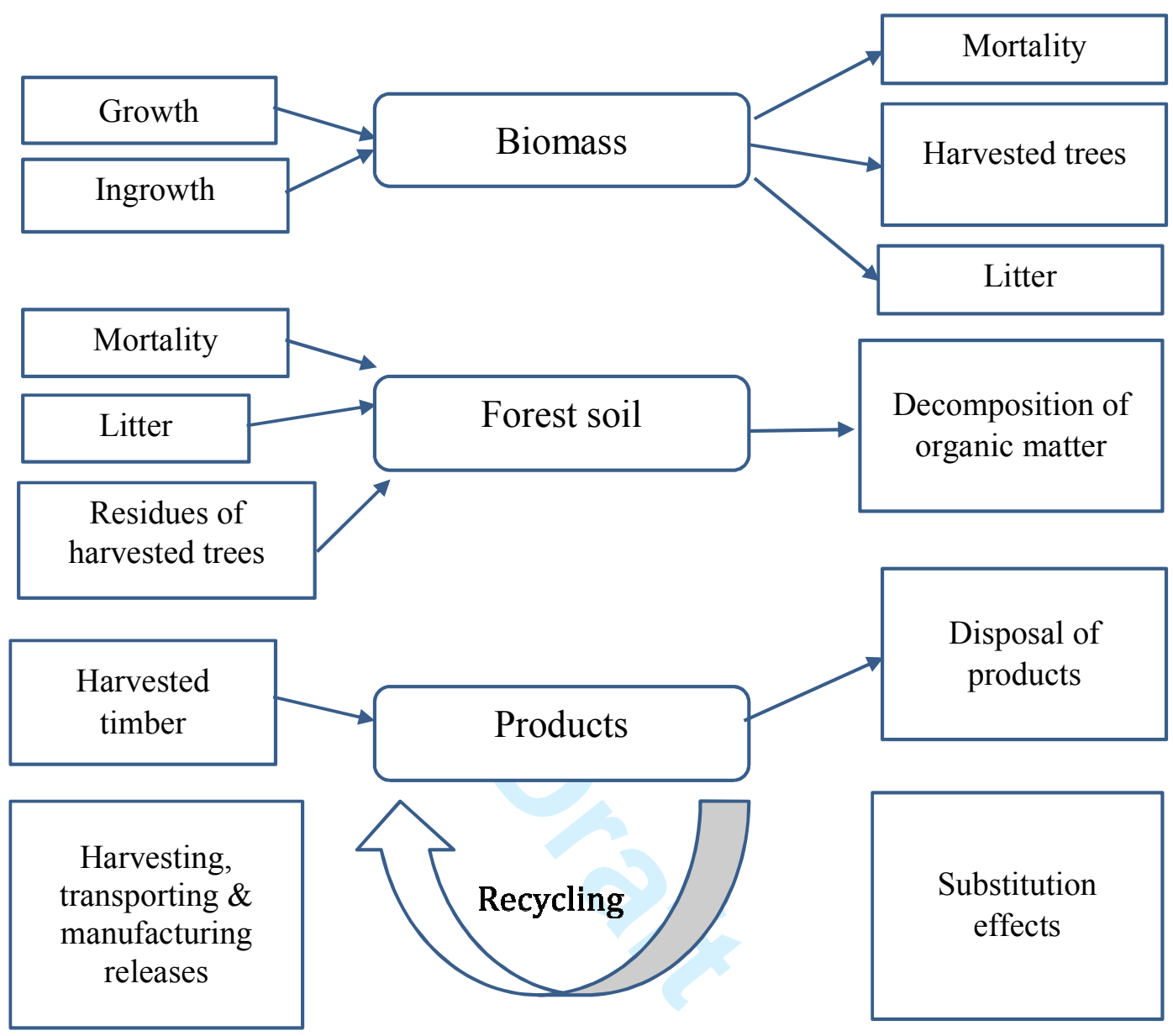

675

676

677

678 releases from harvesting, transport, and manufacturing were included in the carbon balance of

679 wood products. 


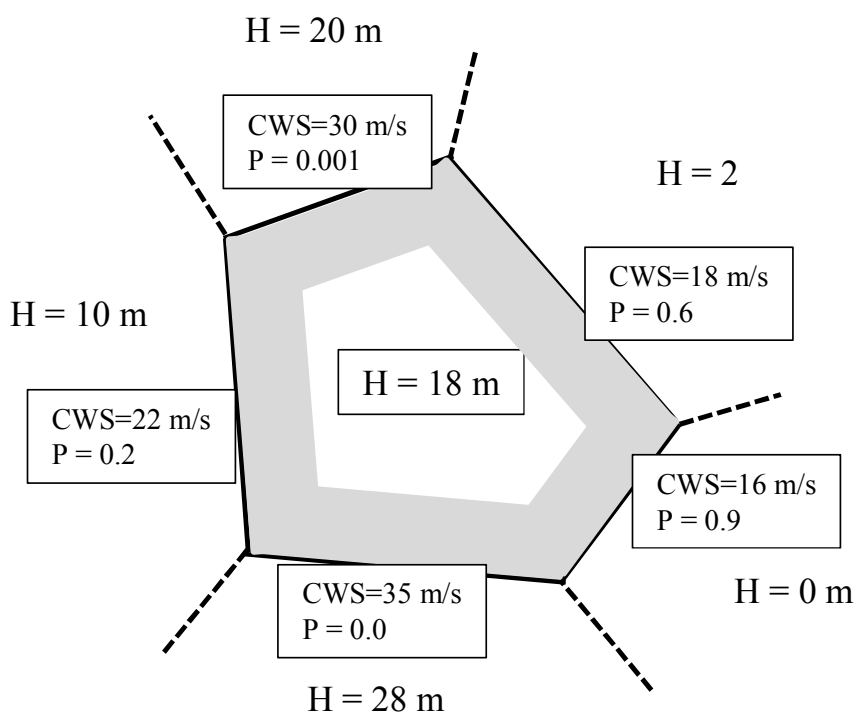

680

681 Figure 3. The principle of simulating wind damage. The critical wind speed (CWS) is

682 calculated for each edge of the subject stand using the characteristics of both the subject and

683 the adjacent stand. Then, the probability of having wind speeds higher than CWS (P) is

684 calculated. Damage occurs within the border zone (gray areas). The width of the border zone

685 is equal to the average tree height of the subject stand. The proportion of damaged trees

686 within the border zone is equal to $0.03 \times \mathrm{P}$, where $\mathrm{P}$ is the probability of wind speed higher

687 than CWS and 0.03 is an empirical parameter. $H$ is the mean tree height of the stand.

688

689 


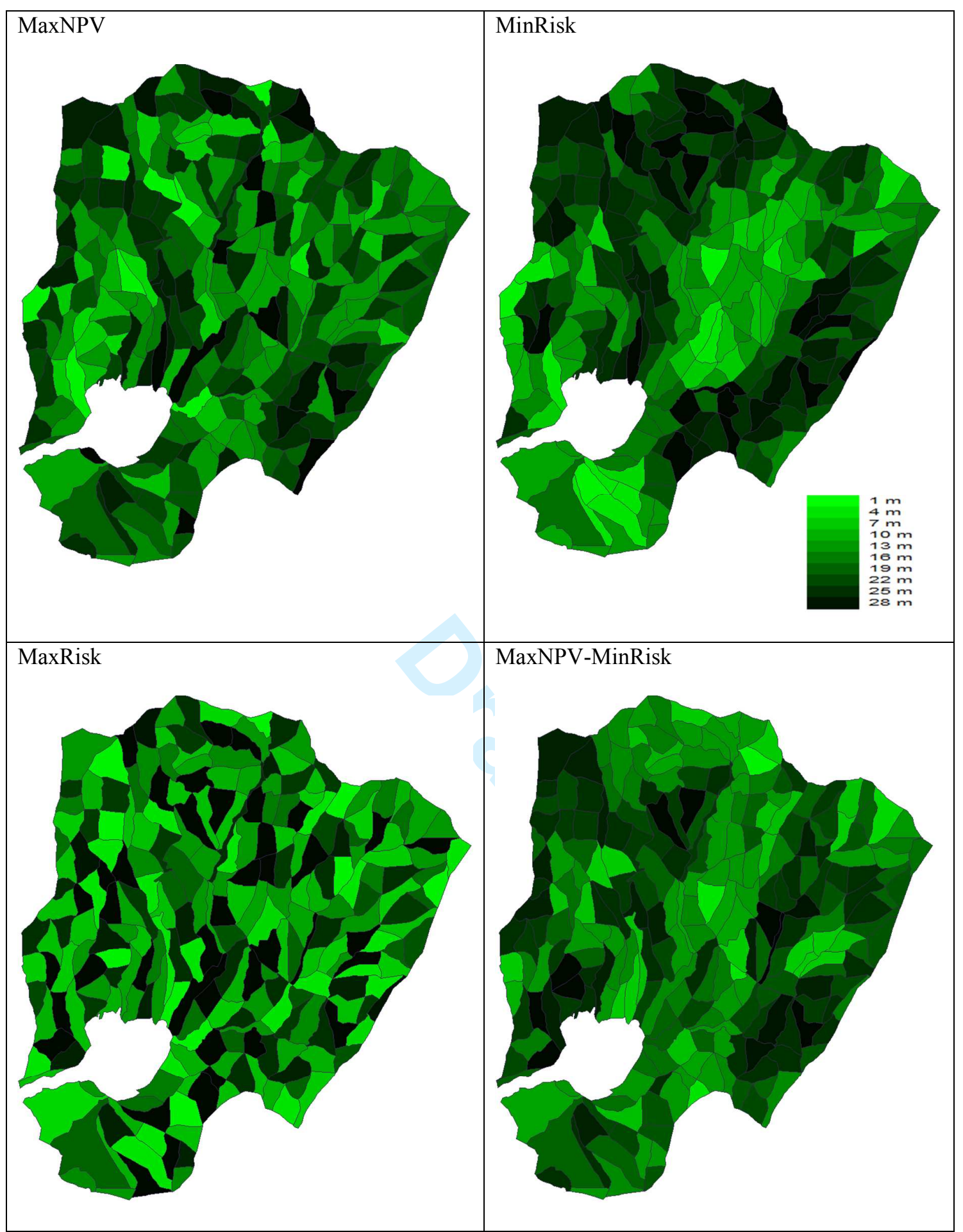

Figure 4. Forest landscape structure (stand height) after 30 years in management plans that

691 maximize NPV (MaxNPV), minimize the risk of wind damage (MinRisk), maximize the risk

692 of wind damage (MaxRisk), and simultaneously maximize NPV and minimize the risk of

693 wind damage (MaxNPV-MinRisk) under the current climate. 
694

695
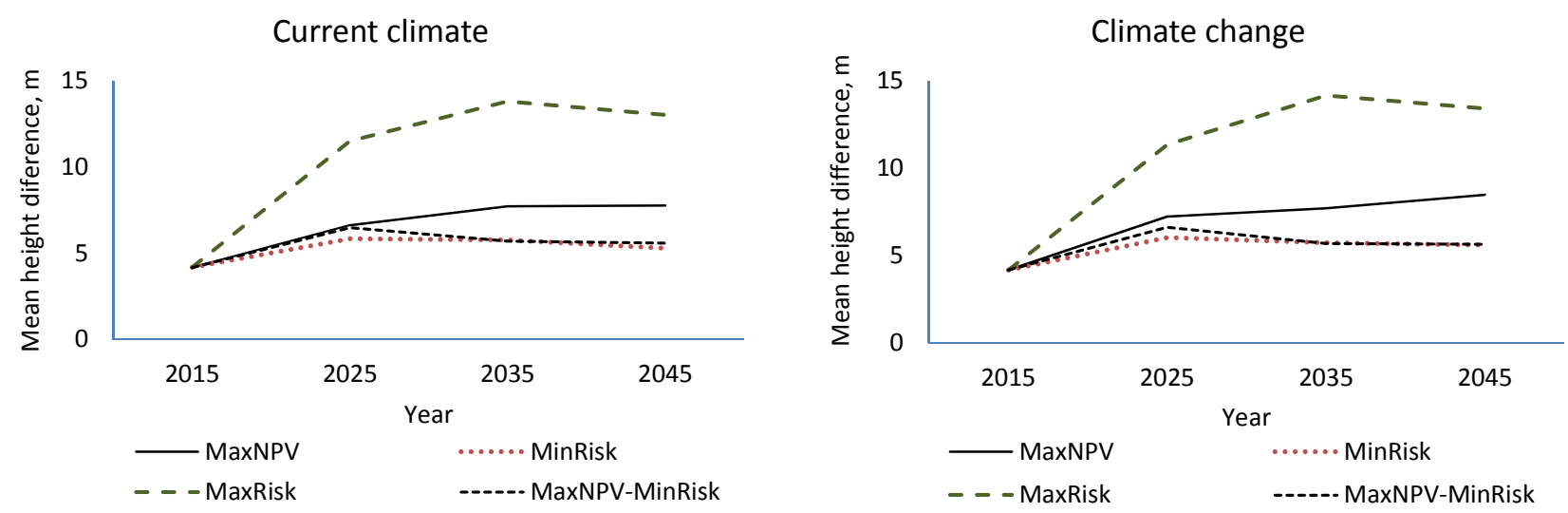

696 Figure 5. Mean stand height difference between adjacent stands under four management plans

697 from 2015 to 2045 (see Table 3 for more detailed explanations of the management plans)

698 under the current and gradually changing climate.

699 


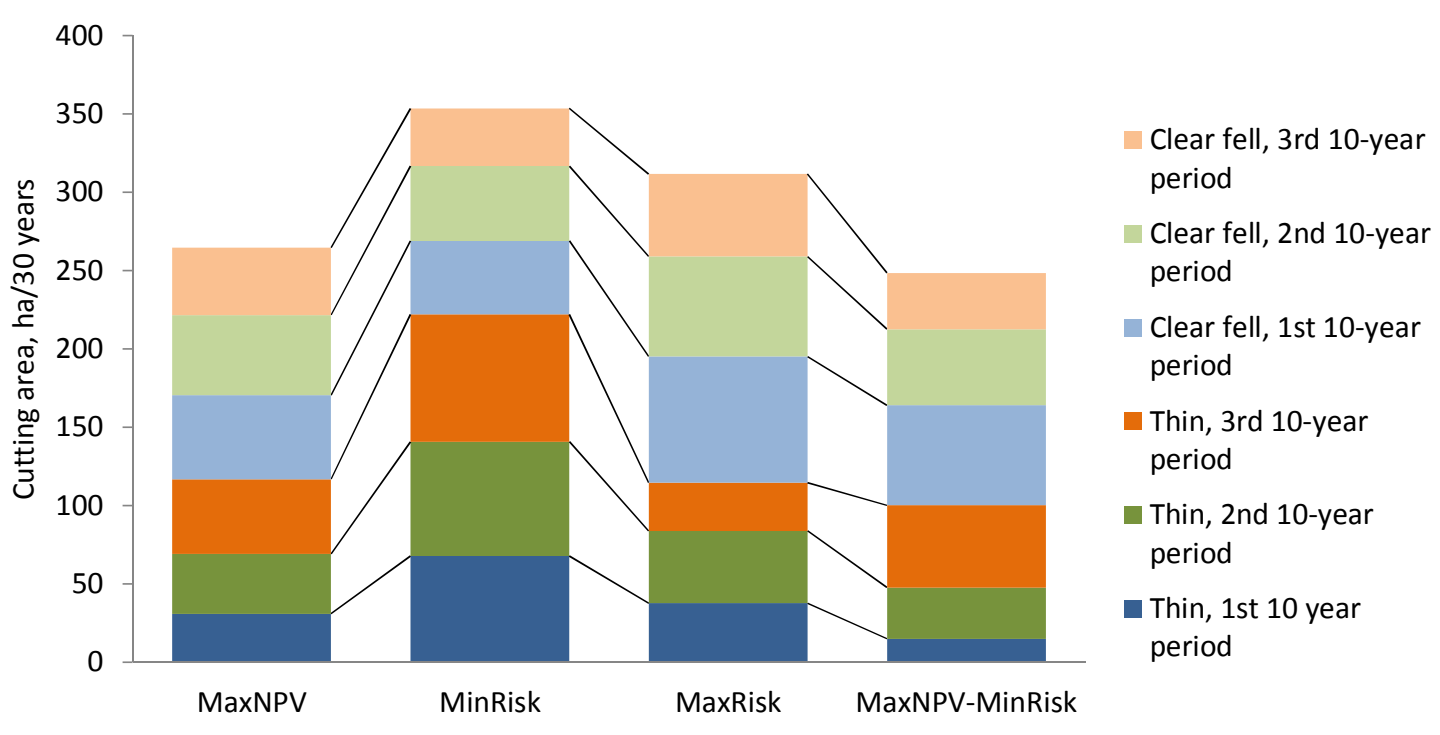

700

701 Figure 6. Thinned and clear cut areas under the current climate for the three 10-year periods

702 in four management plans (see Table 3 for more detailed explanations of the management 703 plans).

704

705 


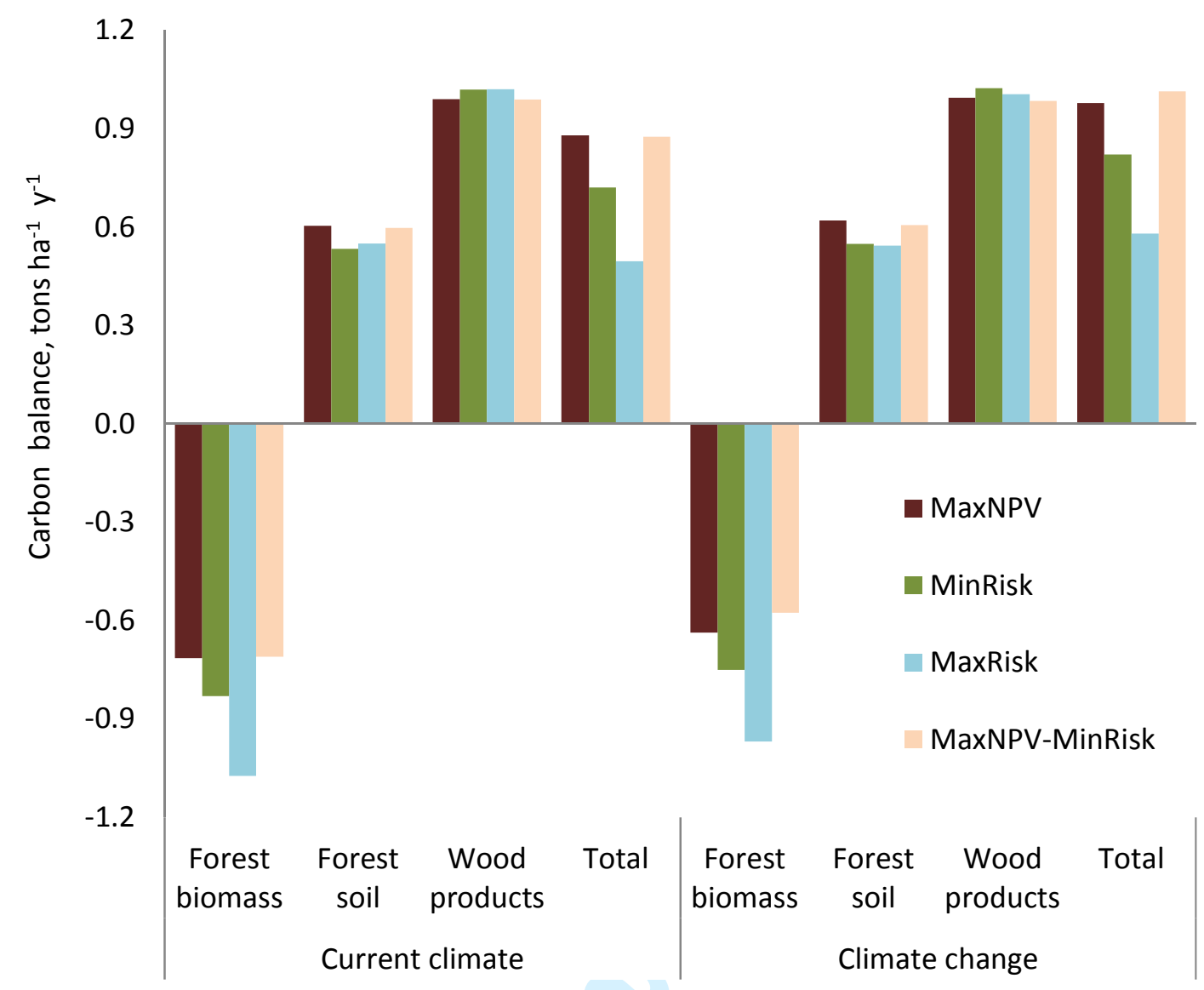

707 Figure 7. Carbon balance of forest biomass, forest soil, and wood products and total carbon

708 balance of forestry under the current and gradually changing climate in four management

709 plans (see Table 3 for descriptions of the management plans).

710 


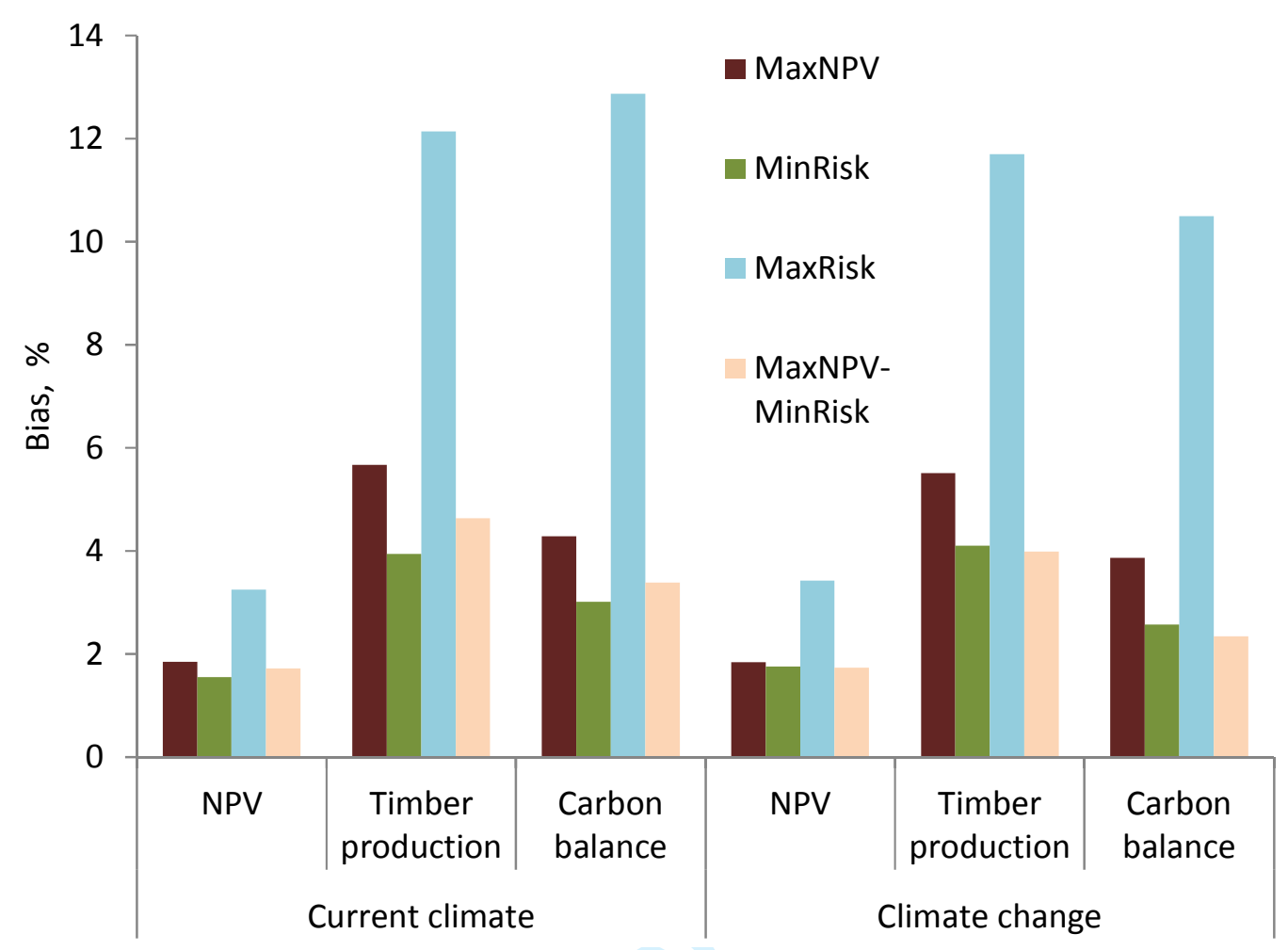

713 Figure 8 . Bias (\%) in the NPV, timber production, and total carbon balance of forestry caused

714 by the omission of wind damage from calculations (positive bias means overestimation) under

715 the current and gradually changing climate in four management plans (see Table 3 for

716 descriptions of the management plans). 


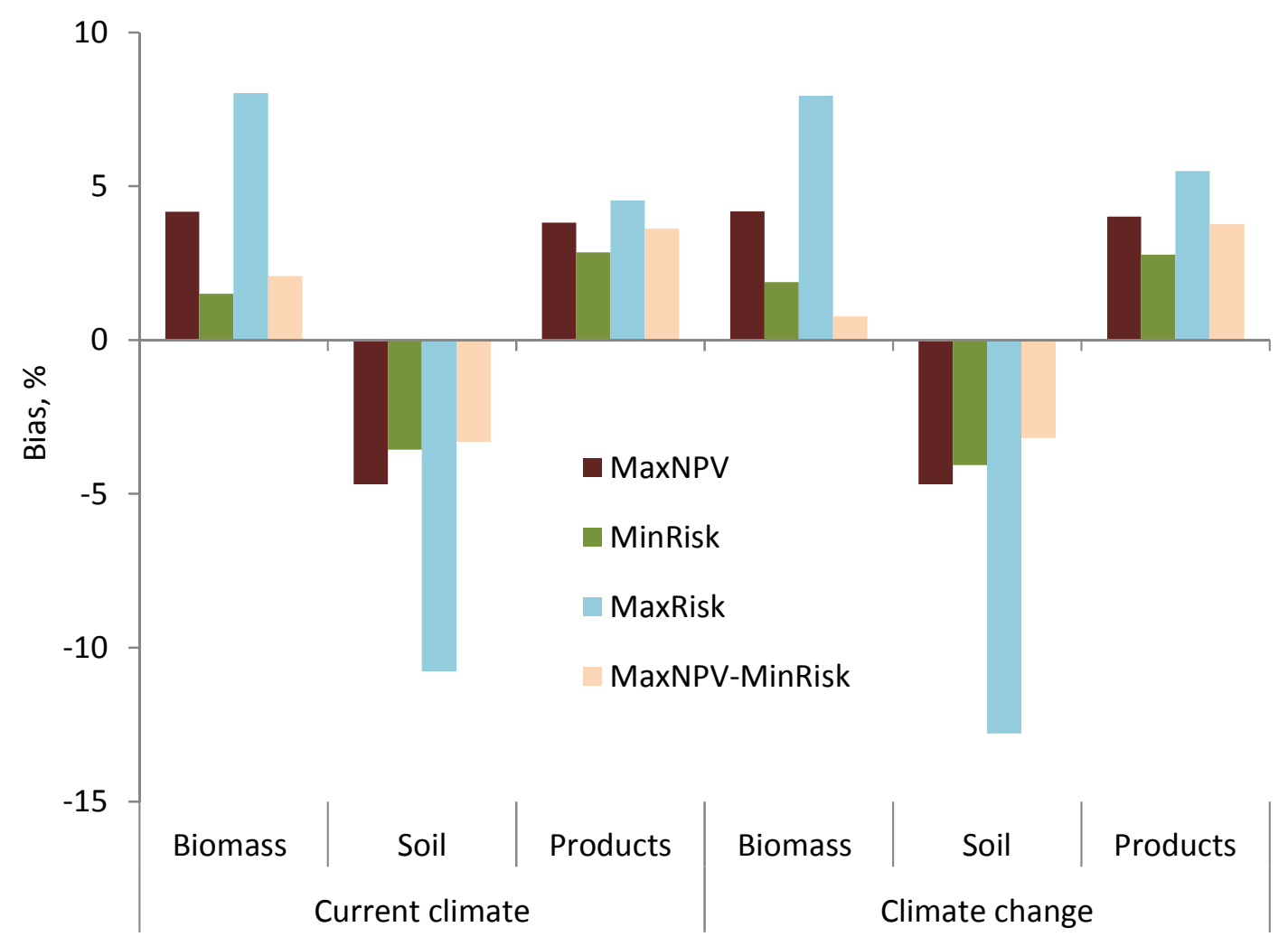

Figure 9. Bias (\%) in the components of the total carbon balance of forestry (living biomass,

720 forest soil, and wood products) caused by the omission of wind damage from calculations

721 (positive bias means overestimation) under the current and gradually changing climate in four 722 management plans.

723 